\title{
USING ICT TO CONTACT THE TARGET CULTURE: TEACHERS' VIEW
}

\author{
LUCIANA CAFFESSE ${ }^{1 \mathrm{~A}} \&$ TERESA GUASCH ${ }^{\mathrm{B}}$ \\ Alndependent Researcher / BUniversitat Oberta de Catalunya (Spain)
}

\begin{abstract}
While information and communication technologies (ICT) have made speakers of and content from the target foreign culture easily accessible to learners and teachers alike, they may cause conditions for FL teachers. This study sought to uncover the nature and extent of FL teachers' use of ICT to contact the target culture, both for instruction and teachers' informal lifelong learning. By means of a survey, interviews and a mini-group interview with students, we portrayed the FL teachers' knowledge, beliefs, context, and behaviour in terms of ICT, and scrutinized how they are related. Findings showed that while teachers and students are sufficiently ICT-skilled and equipped, informal exchanges on the Internet are the exception. Excerpts from the interviews are presented in association with quantitative results.
\end{abstract}

Key words: Information and Communication Technologies, foreign language teaching, lifelong learning, informal learning; videoconference.

\section{Introduction}

Foreign language $(\mathrm{FL})$ learning has become an asset worldwide, and FL teachers are key agents in this achievement. Teaching a foreign language (FL) entails considerable more challenge than teaching a second language. Teachers are expected to provide contact and practice with the target language and be advised of cultural updates such as neologisms and new social entities. This study explored the two main aspects of teachers' professional practice: teaching, and learning as an informal and autonomous endeavour, also called 'lifelong learning' (LLL).

\section{Using ICT to contact the target culture}

With a global scope, lifelong learning is tied to the strategic objectives of all societies (e.g. Fauré, 1972; Delors, 1996; Organisation for Economic Cooperation and Development, 1996; European Commission, 2000; Grace, 2013), and learning a language represents a complete example of a lifelong task (Council of Europe, 2001; Benson, 2013). In that continuous endeavor, informal learning becomes essential for a language learner's development because of its more authentic out-of-the-classroom language experience (Eaton, 2010; Oxford, 1996; Benson and Reinders, 2011; Richards, 2014). With the advent of ICT2, information and knowledge can flow across regions, allowing contact in real time on the internet with many others so transcending geographical distance (Urry, 2002). Thus, the global Internet user population has grown to include one third of the world's population ${ }^{3}$, offering a myriad of possibilities for intercultural interaction (Thorne, 2010) with native or proficient speakers of the target language located anywhere. Research shows evident support for the use of ICT in teaching language skills (e.g. Bates and Poole, 2003;

\footnotetext{
1 E-mails: luciana@agora3.net / tguaschp@uoc.edu

2 ICT include "all communication devices or applications, such as computers, the Internet, broadcasting technologies (radio and television), and telephony, as well as the various services and applications associated with them, such as social media or social networking tools, videoconferencing and distance learning" (Antoniadou, Canals, Mohr, and Zourou, 2011, p. 13).

${ }^{3}$ www.internetworldstats.com
} 
Egbert and Hanson-Smith, 1999; Bonk and Zhang, 2008; Antoniadou, Canals, Mohr, and Zourou, 2011) since sustainable communication with people in distant locations seems a means for 'authentic, direct, and speedy access to native speakers and their cultures' (Kramsch and Thorne, 2002), thus offering advantages over the traditional language teaching approaches (Warschauer, 2006). These new approaches and networks benefit students and they can also forge links among instructors, vitally supporting teachers during the demanding professional-development process of learning (Müller-Harmann, 2007). Graph 1 represents the typical scenario for teachers:

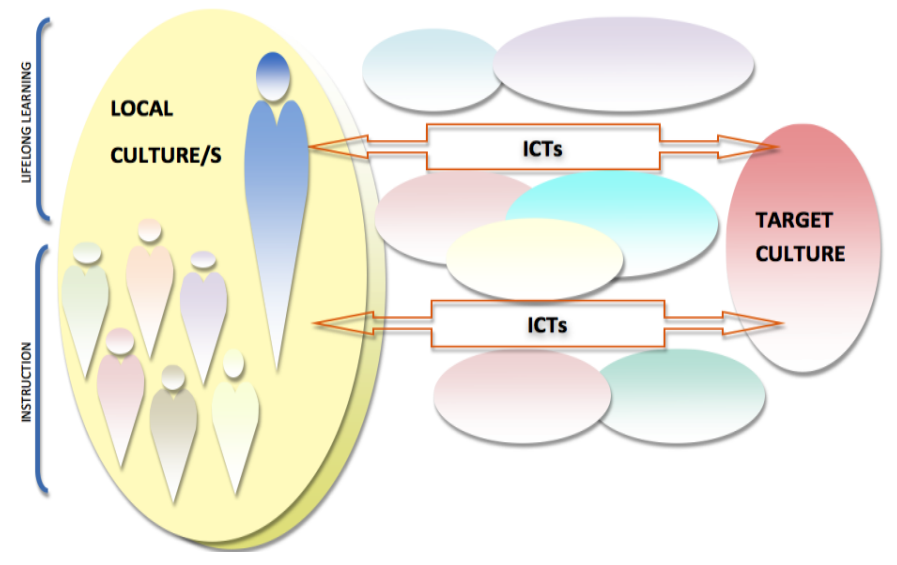

Graph 1. Schema of ICT mediation with the target culture for LLL and instruction.

Computer-assisted language learning (CALL) has more than fifty years of history as a sub-field of second language development research focussing on in-class or instructionally related uses of technology (for discussions, see Bax, 2003; Chapelle, 2009; Hubbard, 2009). Many useful and consistently corroborated findings have emerged from this literature (for reviews, see Chun, 2008; Thorne, 2008a; Couros, 2010; Ducate and Nike, 2011; Johnson, Smith, Willis, Levine, and Haywood, 2011; Warschauer, 2011). Communicating has stepped far ahead when massive communication by email and chat was complemented with the Voice over Internet protocol (VoIP) thus contributing with audio- and/or videoconferencing to FL pedagogy (Richards and Schmidt, 2002; Mullen, Appel, and Shanklin, 2008). Since then, calls can be made over the Internet across the world at no marginal cost, through free software such as Skype or GoogleTalk, even replacing landline technology (Graddol, 2006). Research has shown that online language exchange projects of this nature can contribute to the development of learner autonomy (O'Rourke, 2005; Schwienhorst, 2000; Newby et al. 2007), linguistic accuracy (Kinginger and Belz, 2005; O'Rourke, 2005; Ware and O'Dowd, 2008), intercultural awareness (Müller-Hartmann, 2000; O'Dowd and Ritter, 2006; Ware, 2005), intercultural skills (Belz and Müller-Hartmann, 2003; Thorne, 2010), electronic literacies (Hauck, 2010), and task development (Appel and Gilabert, 2002; Furstenberg, Levet, English, and Maillet, 2001; Müller-Hartmann, 2000; O'Dowd and Waire, 2008, 2009).

With the growing use of CALL, various second language learning theories came about and emphasized the need for a unifying theory (Thorne and Smith, 2011). Most Internet-based CALL research has focused on institutionalized online international partnerships of structured collaborations (Thorne, 2010), which disregard the countless possibilities for intercultural interaction that open up in freely chosen social media. Siemens' (2005) connectivist theory of learning is characterized by learning environments with multiple partners in an open, dynamic and chaotic network. And although connectivism acknowledges the facilitating role of technology in the process of personal network creation, it contemplates the building of online as well as offline learning communities. Connectivism has broader scope than other learning theories as it is situated on different epistemologies (Bell, 2011), and thus parallels the principles of foreign language learning perspectives such as Vigotskian sociocultural theory (Thorne, 2008b), the interaction approach (Smith, 2003), and the ecological approach (van Lier, 2004).

The best-practice sought in the study entailed the use of online social network/s (e.g. Skype, Facebook, Twitter or other specifically for FL learning) to make connections with persons or groups with whom s/he shares interests and can sustain an exchange (i.e. through videoconferencing, web-based calls, chat, etc.). 
Ideally, that exchange takes the form of conversational interaction, which has been considered essential for FL acquisition (Hymes, 1971; Krashen, 1981; Hatch, 1978; Long, 1996; Pica, 1994). Any of these learning activities may take place beyond the classroom walls with as varied interlocutors as possible.

In secondary schools, online intercultural exchange projects have been supported by major platforms such as ePals ${ }^{4}$ and the European Union's Etwinning ${ }^{5}$. For example, the European project NIFLAR ${ }^{6}$ studied the added value that integrating synchronous collaboration through video-web communication or virtual words (e.g. Second Life ${ }^{7}$ ) might have in language learning (Krooshof, Oldeman, de Graaff, 2011; Canto, Jauregi, and van den Bergh, 2013). Also, social networks that pair language learners with native speakers of the target FL help each other learn (e.g. Livemocha ${ }^{8}{ }^{9}$, Busuu ${ }^{10}$, Italki ${ }^{11}$, and Myngle ${ }^{12}$ ).

In a recent report of the INTENT project ${ }^{13}$ about the integration of telecollaborative networks in European Universities, (Helm, Guth, and O'Dowd, 2012), one case's aim was:

to open the student's network to include peer support chosen by the individual from native speakers, and encourage awareness of the advantages and disadvantages this can bring. Increasing the choice and making it as easy as possible to find people who share your interests for social as well as academic reasons seems important.' (Ibid, p. 74)

Although still within an institutional structure, the relatively informal and 'class-independent' nature of this exchange 'has avoided many of the problems which telecollaborative teachers often encounter' (Ibid, p. 74). If language teaching has become more exciting, it has also become considerably more complex (Kern and Warschauer, 2005). Organizing and implementing telecollaboration projects in foreign language curricula is not an easy endeavour (Belz and Thorne, 2006; Guth and Helm, 2010), as pedagogical, organizational and technical issues have to be addressed before cross-cultural interaction sessions can be carried out (O'Dowd and Ritter, 2006; O'Dowd, 2011; Thorne, 2003). These issues make many teachers reluctant to integrate telecollaboration in their teaching, as they are more aware of the burden such initiatives might impose than of the benefits they might have for language learners (Canto, Jauregi, and van den Bergh, 2013).

Designed for FL teachers, SpeakApps ${ }^{14}$ is a multilingual European project, which offers free tools and methodologies online to encourage language students to practice oral skills (Appel, Santanach and Jager, 2012). Also, the DOT ${ }^{15}{ }^{16}$ project is a training kit for language teachers, which promotes up-to-date online teaching projects including bite-size activities for online language teacher training, suggestions for reflective activities and collaborative tools for sharing self-training experiences.

Regarding teacher learning, the Pan-European case study conducted by Kelly, Grenfell, Allan, Kriza, and McEvoy (2004) on secondary school L2/FL teacher training, provides a frame of reference for FL teacher pre- and in-service education, which recommends training in collaboration and networking inside and outside the immediate school context. These shifts in contexts, purposes, and genres associated with 'new-media-in-the-wild', i.e. the provision for learners to interact freely in open networks that they build (Thorne, 2010, p. 158), make it necessary to reassess the role of the teacher in telecollaborative exchanges with a responsive and proactive vision of FL instruction' (O'Dowd, 2007; Thorne, 2010). For Fitzpatrick and

\footnotetext{
${ }^{4}$ ePals.com

${ }^{5} \mathrm{http}: / / w w w . e t w i n n i n g . n e t$

${ }^{6}$ http://www.niflar.eu

${ }^{7}$ secondlife.com

8 http://livemocha.com

9 http://www.tesl-ej.org/wordpress/issues/volume15/ej59/ej59m1/

$10 \mathrm{http}: / /$ busuu.com

11 http://italki.com

$12 \mathrm{http}: / /$ myngle.com

$13 \mathrm{http}: / /$ es.slideshare.net/franhelm/the-intent-project

$14 \mathrm{http}: / /$ moodle.speakapps.org/

15 http://dots.ecml.at/

$16 \mathrm{http://www.ecml.at/tabid/277/PublicationID/76/Default.aspx}$
} 
Davies (2003), these changes necessitate a "shift of paradigm" in teacher / student roles. Teachers are called upon to abandon traditional roles and act more as guides and mentors, exploring the new media themselves as learners and acting as role models for their learners.

\section{FL teacher's view}

We framed the study drawing on Bandura's (1977) Social Cognitive Theory, which emphasizes how personal (cognitive), environmental and behavioural factors interact to determine behaviour. For example, teachers' performances (behavioural factors) are influenced by how school policies (environmental factors) affect teachers themselves (cognitive factors) by. Graph 2 shows the social cognitive model.

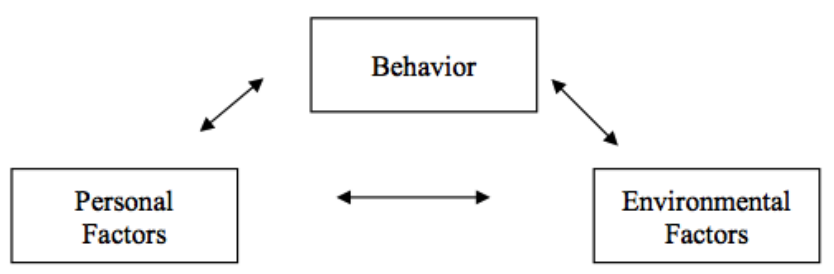

Graph 2. Overview of Social Cognitive Theory (Bandura, 1977).

Empirical research has since confirmed Bandura's theories, and most researchers agree that cognitive variables mediate the relationship between an individual's environment and his/her behaviour (Lathem and Pinder, 2005). As regards FL teachers, research has shown that the social, institutional, instructional and physical settings in which teachers work have a major impact on their cognitions and practices (Borg, 2003, 2006). However, merely providing teachers with the equipment is not enough; many teachers do not take advantage of these new technologies in their classrooms (Kang, 2007), and it is necessary to convince them of the benefits (Lam, 2000; Cuban 2003).

Research has proved that teacher cognitions and practices are mutually informing (Borg, 2003, Borg, 2006; Richards 2009; Pajares, 1992; Cuban, 1993; Freeman 1996, 1998; Freeman and Johnson, 1998; Richards and Nunan, 1990; Scovel 2001). Teachers' attitudes to ICT and appropriate concepts for the orchestration of learning will decide whether the desired outcomes can be achieved and whether a major shift in the culture of learning is possible (Fitzpatrick and Davies, 2003). In the analysis of cognitive factors, it has been difficult to study how the meaning of beliefs differs from that of knowledge (Pajares, 1992). An example likely to happen in the FL teacher scenario is how a teacher thinks s/he masters teaching, and how s/he really does. Mishra and Koehler's (2006) Technological Pedagogical Content Knowledge (TPACK) model addresses the combination of knowledge that teachers require in the 21 st century, and gives a place to the knowledge of how to employ technologies' powerful resources to best affect learning.

Drawing on Bandura's model to better investigate FL teachers' professional practice in terms of ICT, we devised a simple schema where the 'personal factors' item is divided into 'Knowledge' and 'Beliefs'. While these two categories are common to Instruction and Lifelong Learning, the Context and Behaviour rings were analysed in terms of LLL and instruction (See Graph 3). 


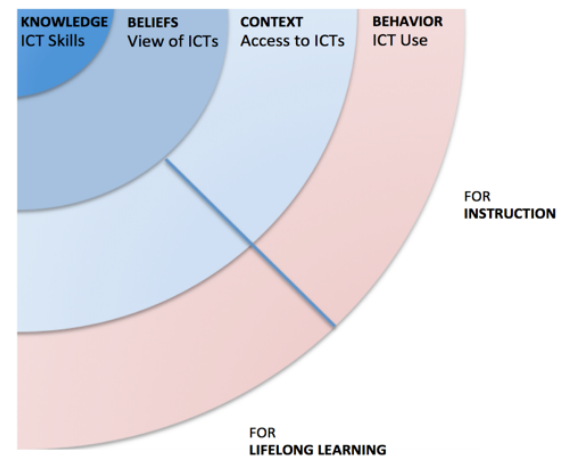

Graph 3. Conceptual schema of a FL teacher's professional practice.

In the schema, the four rings are attributed representations as follows:

The Knowledge ring symbolizes procedural knowledge, i.e. the know-how to videoconference, chat, etc.) either for instruction or lifelong learning purposes. The Beliefs ring symbolizes stated perceptions (e.g. how easy and useful they think ICT are for FL instruction). The Context ring symbolizes teachers' facilitators such as equipment, rooms, etc., as well as institutional constraints, i.e. financial and methodological requirements (Newby et al., 2007). The Behaviour ring symbolizes recalled use of a specific ICT tool to access speakers or content in the target culture.

\section{Method}

\subsection{Research Context and Participants}

The teachers in focus $(\mathrm{N}=3,327)$ were in-service and teach foreign languages (i.e. English, French, German, Italian, Basque, etc.) serving the 547 public secondary schools and 42 Official Language Schools (Escuela Oficial de Idiomas, EOI) in Catalonia, an Autonomous Community within Spain. These two school networks are different; EOls enrol students from 16 to adults and offer a broader scope of foreign languages (e.g. Arab, Russian, Chinese, Japanese, Dutch, and Greek).

\subsection{Data Collection and Data Analysis}

The research process was threefold. Firstly, teachers accessed a 68-item survey online ( $\mathrm{N}=420)$. For the survey instrument, the research constructs were operationalized using multi-item scales. Secondly, the statistical analysis of questionnaire data provided the list of interviewees $(\mathrm{N}=10)$; the selection criteria applied being teachers' capability to use videoconferencing software (VoIP $)^{17}$. This selection draws on the fact that videoconferences can be made over the Internet across the world at no cost (Graddol, 2006), and that they facilitate the most comprehensive form of dialogical interaction accessible either from school or home settings. Thirdly, students of one of the interviewees $(\mathrm{N}=3)$ participated in a mini-group interview (Greenbaum, 1998) in order to corroborate and further explore one interviewee's seemingly outstanding practice.

17 E.g. Skype, http://www.skype.com which supports free video, chat, voice messaging, and screen sharing, and chargeable for landline and mobile phone calls, group videoconferencing, and SMS messages. 


\section{Findings}

Overall, about $70 \%$ of the participants were more than 40 years old, taught in secondary schools, and had taught for longer than ten years. Following, findings organized as per ring of the schema.

\subsection{Knowledge}

The self-report scale listed ICT skills particularly useful for communication with the target culture. While around $80 \%$ can chat and text on the smart phone, almost a half can edit sound or video files, convert the sound of a video into MP3, and create a blog or web site. However, only $23 \%$ can setup a videoconference, which indicates that they are not fully aware of its comprehensive service for conversational contact with the target culture.

Chi-square tests revealed a strong correlation at the $p<.001$ level between ICT skills and age; the younger, the more ICT-skilled. The following interview excerpts confirm this condition:

There are teachers around the age of 50 who still prefer to teach 'from the front' and find it hard to implement task-based, interactive learning and student self-assessment. Imagine the "jump" it means for them to integrate ICT. When we discuss in meetings about using Moodle, they are against.

My older colleagues keep thinking that students know more than themselves and that this condition will undermine teacher authority.

Although age seems a digital-divide issue, best practice teachers belong to the older range of the sample (>40 years old). The reported factor that might encourage less skilled teachers to try new tools and activities is the 'pushing' effect of having younger and more skilled colleagues in the language department and the agreed concept that 'ICT provide prestige'.

Those acknowledging a lower ICT Knowledge mostly feel threatened by student misuse of ICT and displaced by ICT. This suggests that teachers' acquisition of techno-pedagogical content knowledge (Mishra and Koehler, 2006) not only would increase ICT use for LLL and instruction but would also raise teachers' self-confidence (Bandura, 1977).

The chi-square test showed strong correlation between listed beliefs and almost all ICT knowledge items (e.g. 'I can chat'), which shows the effect of beliefs on the decision to acquire knowledge, and further confirms that 'teacher cognitions and practices are mutually informing' (Borg, 2003).

The $80 \%$ reported having been completely free to get started with ICT, and over one third of these believe that 'when started, it was too late.' Thus, such 'freedom' to start learning or teaching with ICT may not be entirely positive, as this comment illustrates.

In fact, there is no imperative to use ICT, and there is no healthy period for adaptation either.

\section{2 Beliefs}

\section{About ICT to contact the target culture}

While teachers assess ICT as an inexpensive way for students to continue learning the FL on a lifelong basis, that appreciation does not apply to themselves as lifelong learners. One third of the teachers think 
that immersion is the only way to learn a language, and one half think that online language learning is a myth. This mistrust of ICT reveals that teachers who are reluctant to use ICT to contact the target culture are not few. This overall result matches the finding in Stevens (2010) of the 'very common belief that language learning is intrinsically related to face-to-face communication and immersion in the target culture' (p. 32).

Also, most respondents $(70 \%)$ preferred 'contact with native speakers where the target language is official'. This belief represents a restraint to the possibilities that ICT offer for speaking practice. The following comment underlines the benefits of a more open approach in this respect:

My aim is teaching English as vehicular language, to communicate with speakers of any language who learn English. It has been so since I found out that I could talk in English with Vietnamese about their country and customs. In that way, the scope of possibilities is huge. I can search for school councils worldwide, target a level similar to that of my students, and it is just making contact.

\section{About teaching with ICT}

The number of teachers threatened by students' inappropriate ICT practices like plagiarism rises along with the number of years in instruction.

\begin{tabular}{|l|l|l|l|l|l|l|l|}
\hline \multicolumn{2}{|c|}{} & \multicolumn{5}{|l|}{ Seniority (years) } & \multirow{2}{*}{ Total } \\
\cline { 2 - 8 } \multicolumn{2}{|c|}{} & $1-5$ & $6-10$ & $11-15$ & $16-20$ & $>20$ & \\
\hline \multirow{3}{*}{$\begin{array}{l}\text { Plagiarism } \\
\text { is a Worry }\end{array}$} & Disagree & $7.9 \%$ & $8.4 \%$ & $9.9 \%$ & $8.1 \%$ & $11.1 \%$ & $45.4 \%$ \\
\cline { 2 - 8 } & Agree & $4.4 \%$ & $8.4 \%$ & $13.1 \%$ & $11.6 \%$ & $17.0 \%$ & $54.6 \%$ \\
\cline { 2 - 8 } & Total & $12.3 \%$ & $16.8 \%$ & $23.0 \%$ & $19.8 \%$ & $28.1 \%$ & $100.0 \%$ \\
\hline
\end{tabular}

Table 1. Relation between Seniority and Worry about student misuse of ICT.

Students' misuse of ICT is a bigger concern for secondary school teachers than for EOI teachers. This difference may be associated with student motivation and how that environmental condition affects teacher Beliefs (Rádai, 2003; Bandura, 1977). About students' misuse of ICT, two teachers described their experience:

I do not assign writing tasks for homework, otherwise it will be copied or googled, but not the student's true job.

Some not so good students submit perfect texts that are a copy-paste from the Internet. I have to spend time to google the text until I find the source web site.

About one third of the sample think that 'Students surpass teachers concerning technology', and acknowledged that 'When s/he decided to start using ICT it was already too late'. Others believe that the fast development of ICT is a challenge for teachers and students alike. A small group claimed that students manage a small number of tools. The following excerpts reflect the three positions: 
Students extensively surpass me about ICT. Just today, I had to give a PowerPoint to a student from my computer and he gave me a pen drive. 'Do it yourself' -l told him.

I can't know about everything and neither can students. Then, I teach what I know and they teach me...The other day they taught me how to use the webcam. We have to 'change the chip', but there is still the stereotype of the sage teacher, and teachers are afraid of undermining their authority.

Children do not know as much about ICT as we think. They just know about four or five things for their leisure, but it is our mission to help them know how to use ICT to learn the language and get closer to its culture.

As opposed to this extended teachers' belief of the highly ICT skilled teenagers, the findings of a study conducted with students in Barcelona by Kompen, Edirisingha, and Monguet (2009) revealed unskilled and unaware young students. Then, teachers' belief may have a strong effect even when not grounded in truth.

Over $80 \%$ of teachers believe that students' contact with the target culture requires teachers' continuous cultural update and teacher's guidance. These two reports associated with increased teacher responsibility may be compensated with a general agreement upon 'ICT ease work', as illustrated by a teacher:

The varieties of French can be easily accessed with the resources available on the Internet; recordings by speakers of Belgian, Swiss origin... even within France you find different accents. In that way, students realize there is not just the teacher's pronunciation but many ways that I can bring to the classroom.

This blurry position of teachers about why using ICT to contact the target culture is also seen in Helm, Guth, and O'Dowd (2012); while a few respondents set up their online cultural exchanges 'as a response to learning needs or student requests for authenticity', others see ICT 'as a part of everyday life' (p. 15).

\subsection{Context}

Drawing on the concept of 'first digital divide' (Hagittai, 2002), which involves the quantity and quality of available equipment, the focus was set on teacher's and students' individual availability of computer or smart phone and internet connection, as well as how ICT-equipped the school was to contact the target culture. A vast majority of teachers have 'unlimited access to a computer' and 'unlimited internet', and over half of the respondents estimated 'student at-home access to computer resources' as massive.

For the great majority, the school setting is equipped with video, audio and overhead projector, essential to exploit online multimedia or group videoconferencing. While half of the teachers may count on broadband Internet, and a PC for each student in the classroom, only $22 \%$ have headphones and microphones for each student. Only $3 \%$ of EOI teachers, but $37 \%$ of secondary schools teachers have 'One computer per student' (as part of the Catalonian '1 $1 \times 1$ Program'18).

Other stakeholders (i.e. parents, government, the labour market) are highly interested in effective FL learning to happen. The milieu is technologically furnished: public wireless Internet and state-of-the-art technology are publicly accessible (in libraries, streets, beaches).

18 Governmental program which targeted public schools and equipped them with overhead projector and digital board connected to a computer, power network for all students using their PCs simultaneously, enough broad band, and wifi. http://www10.gencat.cat/gencat/AppJava/es/actualitat2/2010/00421educat1x1.jsp (in Catalan) 


\subsection{Behaviour}

While the vast majority (89\%) use ICT once a day in personal life, only $60 \%$ use them for instruction, and just $48 \%$ for LLL as depicted in Graph 4.

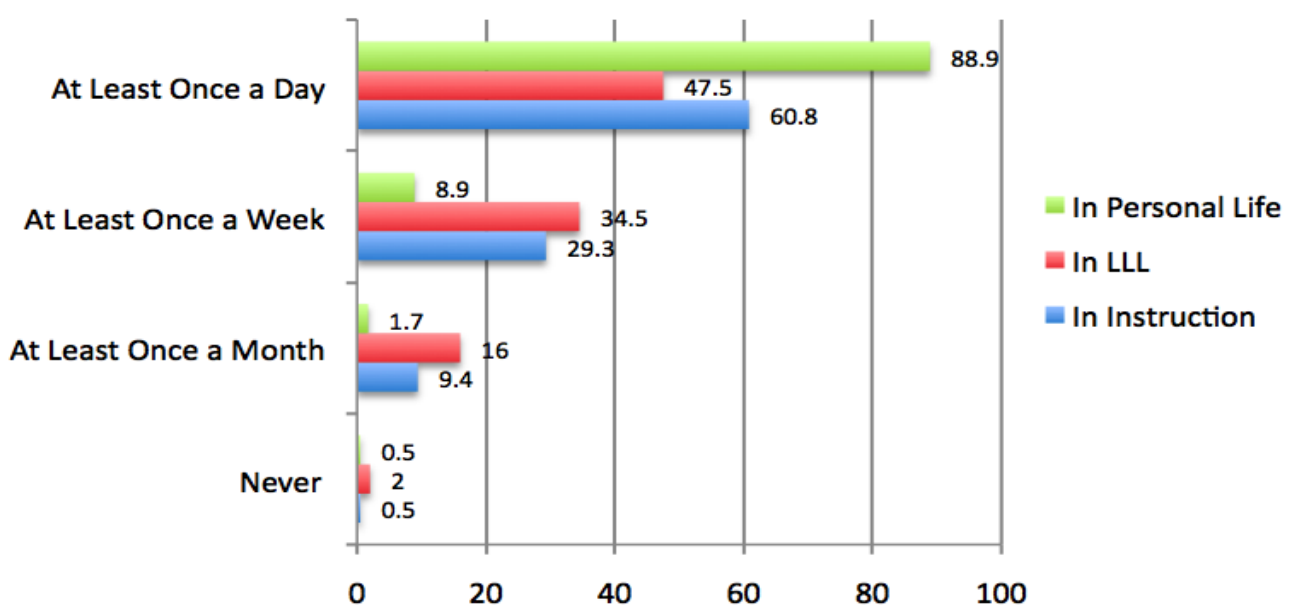

Graph 4. Frequency of ICT use in personal life, LLL and instruction.

Frequency of ICT use 'In Instruction' obviously associates with ICT equipment in the school, and is strongly correlated ( $p=.000)$ with: Knowledge of ICT, confidence-related Beliefs: 'Students surpass me about ICT', and 'When I Started ICT training It Was Too Late $(p=.000)$.

The ICT that teachers use the most for language learning (i.e. videos, TV and radio, followed by social networking and videoconferencing) concur very closely with Stevens' (2010). This hierarchy in use places the emphasis on receptive activities; i.e. reading and/or listening, rather than on conversational interaction, which has been considered essential for FL acquisition (Hymes, 1971; Krashen, 1971; Hatch, 1978; Long, 1996; Pica, 1994).

For professional development, teachers perform twice to four times more formal than informal activities. Some teachers are not aware that a number of activities they perform represent informal learning, e.g. intentionally watching a film in the target language for practicing purposes. This comments reveal teachers' assessment of formal ICT training and independent ICT use to contact the target culture for LLL.

We have often attended courses that for some people were tediously easy whereas for others were extremely difficult.

Once in a while I go to the target culture to get 'recycled, but, naturally, that takes time, money. It is more confortable from home through ICT. It is not just like moving to the target country, but you reach a lot of it.

In instruction, although ICT are the main means to contact the target culture for two in five teachers, the textbook seems to be deeply rooted in the teaching practice, and for not few, the teacher is still the main means of contact with the target culture. As a notable experience, an interviewee reported having accompanied very small groups of English as FL students for short stays in countries where English is a FL (e.g. Germany, Croatia). However, she made no reference to pre- or post-trip contact of her secondaryschool students with their partners abroad. Except for a few innovators, teachers are not applying a connectivist approach (Siemens, 2005) to language learning and teaching. They do not use ICT for building 
out-of-classroom open networks, autonomously choosing appropriate connections within the network, and seeking diversity of language varieties.

The mini-group interview with students sought their viewpoint on a teacher's use of ICT in instruction for two years. She had organized an exchange trip between the French-language class and a Spanishlanguage class in a school in northern France. Students spent one week in each other's town, staying at the students' home on a one-to-one basis. For the pairs to get to know each other as well as their families and friends before the exchange, they used chat, social networks and videoconference, informally, as an out-ofschool activity as informal learning beyond the teacher's control. This exchange went on between the oneweek stays and after them. When describing that activity, the teacher said:

It also happened that individuals not participating in the exchange became friends of the children in Paris through Facebook. [...]. It was like opening a door and the other ones dropped in.

\section{Conclusions}

These findings may contribute to the development of customized training and awareness-raising activities in consideration of these characteristics of teachers and students.

Teachers are ICT-skilled and equipped, and those not using ICT to contact the target culture-seem to ignore the possibilities they offer. Teachers are also duly accredited, which makes them pedagogy knowledgeable; and since they are experienced, they have witnessed the evolution of FL teaching along the last decades. All these attributes favour their trial and implementation of new approaches. For Dooly (2009), teachers, far from being conservative, are eager to bring changes to their practice, though conditions may interfere in that change. Although teachers are ready for informal and self-directed learning, they take twice more formal than other forms of training.

Students are also well ICT-equipped both in schools and at home. Social media, the tool that best adapts for contacting the target culture, are deeply rooted in their personal lives, as this comment depict:

Facebook is an obsession; students associate the computer with Facebook.

However, overall teenage use of ICT in the classroom-especially in secondary schools- involves plagiarism, chaos when watching a video, etc., which does not contribute to teacher's change towards more ICT use. Therefore, teachers should develop the strategies to pedagogically exploit social media and thus break the negative attitude in the classroom.

The educational system provides teachers with considerable equipment to enhance instruction with ICT, and freedom to innovate with syllabi. Formal teacher training seems not to meet the quantity and quality that teachers need. These expressions of interviewees are descriptive:

I am interested in learning not only to teach with ICT but how to overcome the fear for students' multi-tasking.

We have often attended courses that for some people were tediously easy whereas for others were extremely difficult.

Suggestions for future research point to teachers' acceptance of ICT, the evaluation of specific tools to be integrated, and the attitude of students towards ICT for informal learning. 


\section{References}

Antoniadou, V., Canals, E., Mohr, C. \& Zourou, K. (2011). Young people with fewer opportunities learning languages informally: perceptions and uses of ICT and social media. Retrieved from: http://www.openeducationeuropa.eu/el/download/file/fid/23485

Appel, C., Santanach, F. \& Jager, S. (2012). Speakapps: New tools and activities for the development of speaking skills in a second language. Proceedings of the EDULEARN12, 4th International Conference on Education and New Learning Technologies 2-4 July, 2012, pp. 1710-1715.

Appel, M. C. \& Gilabert, R. (2002). Motivation and task performance in a task-based web-based tandem project. ReCALL, 14, pp 16-31.

Bandura, A. (1977). Social Learning Theory. Englewood Cliffs. Prentice Hall.

Bates, A. \& Poole, G. (2003). Effective teaching with technology in higher education. San Francisco: JosseyBass/John Wiley.

Bax, S. (2003) 'CALL—past, present and future', System 31(1), 13-28.

Bell, F. (2011). Connectivism: Its place in theory-informed research and innovation in technology-enabled learning. The International Review Of Research In Open And Distance Learning, 12(3), 98-118. Retrieved from http://www.irrodl.org/index.php/irrodl/article/view/902

Belz, J. \& Thorne, S.L. (Eds.) Internet-mediated intercultural foreign language education (pp. 2-30). Boston, MA: Thomson Heinle.

Belz, J.A. \& Müller-Hartmann, A. (2003). Teachers as Intercultural Learners: Negotiating German-American Telecollaboration along the Institutional Fault Line. The Modern Language Journal, 87(1) 71-89.

Benson, P. (2013). Teaching and researching: Autonomy in language learning. Routledge.

Benson, P. \& Reinders, H. (2011) (Eds), Beyond the Language Classroom. The Theory and Practice of Informal Language Learning and Teaching. Basingstoke: Palgrave Macmillan.

Bonk, C.J., \& Zhang, K. (2008). Empowering Online Learning: 100+ Activities for Reading, Reflecting, Displaying, and Doing. San Francisco, CA: Jossey-Bass.

Borg, S. (2003). Teacher cognition in language teaching: a review of research on what language teachers think, know, believe, do. Language Teaching 36, 81-109.

Borg, S. (2006). Teacher cognition and language education: Research and Practice. London: Continuum International Publishing Group.

Canto, S., Jauregi, K. \& van den Bergh, H. (In press). Integrating cross-cultural interaction through videocommunication and virtual worlds in foreign language teaching programs: is there an added value? ReCALL.

Chapelle, C.A. (2009). The relationship between second Language acquisition theory and computerassisted language learning. The Modern Language Journal, 93, 741-753.

Chun, D. (2008). Computer-mediated discourse in instructed environments. In S. Magnan (Ed.), Mediating discourse online (pp. 15-45). Philadelphia: Benjamins.

Council of Europe (2001). Common European Framework of Reference for Languages: Learning, teaching, assessment. Strasbourg: Council of Europe.

Couros, A. (2010). Developing personal learning networks for open and social learning. In G. Veletsianos (Ed.). Emerging Technologies in Distance Education (pp. 109-128). Edmonton, AB: Athabasca University Press.

Cuban, L. (1993). How teachers taught: constancy and change in American classrooms 1890-1990. $2^{\text {nd }}$ ed. New York: Teachers College Press, N.Y.

Cuban, L. (2003). Why is it so hard to get good schools? New York: Teachers College Press. 
Delors, J. (Chair) (1996). Learning: the Treasure Within. Report to UNESCO of the International Commission on Education for the Twenty-first Century. Paris: Unesco.

Dooly, M. (2009) New competences in a new era? Examining the impact of a teacher training project. ReCALL, 21(3): 352-369.

Ducate, L. \& Nike, A. (Eds.). (2011). Present and Future Promises of CALL: From Theory and Research to New Directions in Language Teaching, CALICO Monograph Series, San Marcos, Texas.

Eaton, S.E. (2010). Global Trends in Language Learning in the Twenty-first Century. Calgary: Onate Press.

Egbert, J. \& Hanson-Smith, E. (eds.) (1999). CALL Environments: Research, Practice, and Critical Issues, Alexandria, Va.: TESOL.

European Commission. (2000). A memorandum on lifelong learning. Brussels: EC.

Fauré E., Herrera F., Kaddoura A.R., Lopes H., Petrovsky A.V., Rahnema M. \& Ward F.C. (1972) Learning to Be: The World of Education Today and Tomorrow. Paris: UNESCO. Retrieved from http://www.unesco.org/education/pdf/15_60.pdf

Fitzpatrick A. \& Davies G. (2003) (eds.). The Impact of ICT on the Teaching of Foreign Languages and on the Role of Teachers of Foreign Languages. Retrieved from: http://www.camsoftpartners.co.uk/docs/ICC_Grahams_Report_Final.htm

Freeman, D. (1996). The unstudied problem: research on teacher learning in language teaching. In D. Freeman \& J. Richards (Ed.). Teacher learning in language teaching. Cambridge: Cambridge University Press. p. 351-378.

Freeman, D. (1998). Doing teacher research: from inquiry to understanding. Boston: Heinle \& Heinle.

Freeman, D. \& Johnson, K. (1998). Reconceptualizing the knowledge base of language teacher education. TESOL Quarterly 32, v.3, p.367-417.

Furstenberg, G., Lewet, S., English, K. \& Maillet, K. (2001). Giving a virtual voice to the silent language of culture: The Cultura project. Language Learning \& Technology, 5(1), 55- 102. Retrieved from http://lt.msu.edu/vol5num1/furstenberg/default.html.

Grace, A.P. (2013). Lifelong learning as critical action: International perspectives on people, politics, policy, and practice. Canadian Scholars' Press.

Graddol, D. (2006). English Next: Why Global English May Mean the End of 'English as a Foreign Language'. London: British Council.

Greenbaum, T. L. (1998). The handbook for focus group research. Sage.

Guth, S. \& Helm, F. (2010). Telecollaboration 2.0: Language, literacies and intercultural learning in the $21^{\text {st }}$ century (Vol. 1). Peter Lang.

Hatch, E. (1978). Discourse analysis and second language acquisition. In E. Hatch (Ed.), Second Language Acquisition. Rowley, Ma.: Newbury House, pp. 401-435.

Hauck, M. (2010). Telecollaboration: At the interface between multimodal and intercultural communicative competence. In S. Guth \& F. Helm (Eds.), Telecollaboration 2.0: Language and intercultural learning in the 21st century (pp. 219-248). Bern: Peter Lang.

Helm, F., Guth, S. \& O'Dowd, R. (2012). University Language Classes Collaborating Online: A Report on the Integration of Telecollaborative Networks in European Universities. Retrieved from http://www.academia.edu/3500729/

Hubbard, P. (2009). General Introduction. In P. Hubbard (Ed.). Computer Assisted Language Learning: Vol. 1 (Critical Concepts in Linguistics). London: Routledge. http://www.stanford.edu/ efs/callcc/callccintro.pdf

Hymes, D. (1971). On communicative competence. In C. J. Brumfit \& K. Johnson (Eds.), The communicative approach to language teaching (pp. 5-26). Oxford: Oxford University Press. 
Johnson, L., Smith, R., Willis, H., Levine, A. and Haywood, K. (2011). The 2011 Horizon Report. Austin, Texas: The New Media Consortium.

Kang, P.T. (2007). Technology, Lifelong Learning, and Effective Foreign Language Instruction Under the Memory Efficient Approach. In Y. Inoue (Ed.), Online Education for Lifelong Learning (pp. 73-97).

Kelly, M., Grenfell, M., Allan, R., Kriza, C. \& McEvoy, W. (2004). European profile for language teacher education: a frame of reference. Southampton, UK: Southampton University www.lang.soton.ac.uk/profile/report/MainReport.rtf

Kern, R. \& Warschauer, M. (2005). Network-Based Language Teaching: Concepts And Practice. Cambridge: CUP.

Kinginger, C. \& Belz, J. (2005). Socio-cultural perspectives on pragmatic development in foreign language learning: Microgenetic and ontogenetic case studies from telecollaboration and study abroad. Intercultural Pragmatics, 2(4), 369-422.

Kompen, R.T., Edirisingha, P. \& Monguet, J.M. (2009). Using Web 2.0 applications as supporting tools for personal learning environments. In Best Practices for the Knowledge Society. Knowledge, Learning, Development and Technology for All (pp. 33-40). Berlin Heidelberg: Springer.

Kramsch, C. \& Thorne, S. (2002). Foreign language learning as global communicative practice. In D. Cameron \& D. Block (Eds.), Globalization and language teaching (pp. 83-100). New York: Routledge.

Krashen, S.D. (1981). Second Language Acquisition and Second Language Learning. Oxford: Pergamon.

Krooshof, S., Oldeman, D. \& de Graaff, R. (2011). Networked Interaction in Foreign Language Acquisition and Research (NIFLAR) Research results: videocommunication at secondary schools. Retrieved from http://cms. hum.uu.n//niflar/index.php?page=documents

Lam, Y. (2000). Technophilia vs. technophobia: A preliminary look at why second-language teachers do or do not use technology in their classrooms. Canadian Modern Language Review, 56 (3), 390-420.

Latham, G.P. \& Pinder, C.C. (2005). Work motivation theory and research at the dawn of the twenty-first century. Annual Review of Psychology, 56, 485-516.

Long, M.H. (1996). The role of the linguistic environment in second language acquisition. In W. C. Ritchie \& T.K. Bhatia (Eds.). Handbook of research on language acquisition. Vol. 2: Second language acquisition. New York: Academic Press.

Mishra, P. \& Koehler, M.J. (2006). Technological Pedagogical Content Knowledge: A Framework for Teacher Knowledge. Teachers College Record, 108(6), 1017-1054. http://punya.educ.msu.edu/publications/journal_articles/mishra-koehler-tcr2006.pdf

Mullen, T., Appel, C. \& Shanklin, T. (2008). Chapter VI: Skype-Based Tandem Language Learning and Web 2.0. In Handbook of Research on Language Acquisition Technologies: Web 2.0. (pp. 101-118). Hershey, PA: IGI Global.

Müller-Hartmann, A. (2000). The role of tasks in promoting intercultural learning in electronic learning networks. Language Learning \& Technology, 4(2), 129-147. Retrieved from http://lt.msu.edu/vol4num2/ muller/default.html.

Müller-Hartmann, A. (2007). Teacher role in telecollaboration. Setting up and managing exchanges. In R. O'Dowd (Ed.), Online intercultural exchange (pp. 41-61). Clevedon, UK: Multilingual Matters.

Newby, D., Allan, R., Fenner A.B., Jones, B., Komorowska, H. \& Soghikyan, K. (2007) European Portfolio for Student Teachers of Languages: A reflection tool for language teacher education. Retrieved from: http://www.ecml.at/epostl

O'Dowd, R. (Ed.). (2007). Online intercultural exchange: An introduction for foreign language teachers (Vol. 15). Multilingual Matters.

O'Dowd, R. (2011). Online foreign language interaction: Moving from the periphery to the core of foreign language education. Language Teaching, 44(3), 368-380. 
O'Dowd, R. \& Ritter, M. (2006). Understanding and working with „failed communication" in telecollaborative exchanges. CALICO Journal, 23 (3), pp. 1-20

O'Dowd, R. \& Waire, P. (2008). Peer Feedback on Language Form in International Telecollaboration. Language Learning and Technology Vol. 12(1).

O'Dowd, R. \& Waire, P (2009). Critical issues in telecollaborative task design. Computer Assisted Language Learning, 22(2), pp. 73-188

O'Rourke, B. (2005). Form-focused interaction in online tandem learning. CALICO Journal, 22(3), 433- 466.

OECD (1996). Guidelines for testing of chemicals. Proposal for updated Guideline 211, Daphnia magna reproduction test. Revisited Draft Document. OECD, Paris, France.

Oxford, R.L. (Ed.) (1996). Language Learning Motivation: Pathways to the New Century. Honolulu: University of Hawaii Press.

Pajares, M.F. (1992) Teachers' Beliefs and Educational Research: Cleaning Up a Messy Construct. Review of Educational Research 62(3) 307-332.

Pica, T. (1994). Research on negotiation: What does it reveal about second language learning conditions, processes, and outcomes? Language Learning, 44, 493-527.

Rádai, P., Bernaus, M, Matei, G., Sassen, D. \& Heyworth, F. (2003). The status of language educators, Graz: Council of Europe / European Centre for Modern Languages. Retrieved from http://archive.ecml.at/documents/pub211E2003Radai.pdf

Richards, J.C. \& Schmidt, R. (2002). Longman dictionary of applied linguistics and language teaching. Harlow, UK: Longman.

Scovel, T. (2001). Learning New Languages: A Guide to Second Language Acquisition. Boston: Heinle \& Heinle.

Siemens, G. (2005). Connectivism: A Learning Theory for the Digital Age. Retrieved from http://er.dut.ac.za/handle/123456789/69

Smith, B. (2003). Computer-mediated negotiated interaction: An expanded model. Modern Language Journal, 87, 38-58.

Stevens, A. (2010). Study on the impact of information and communications technology (ICT) and new media on language learning. European Commission.

Thorne, S.L. (2003). Artifacts and cultures-of-use in intercultural communication, Language Learning \& Technology 7(2), 38-67. Retrieved from http://llt.msu.edu/vol7num2/thorne/

Thorne, S.L. (2008a). Mediating Technologies and Second Language Learning. In Leu, D., Coiro, J., Lankshear, C. \& Knobel, M. (eds.), Handbook of Research on New Literacies. Mahwah, NJ: Lawrence Erlbaum.

Thorne, S.L. (2008b). Transcultural communication in open Internet environments and massively multiplayer online games. In Magnan S. (ed.), Mediating discourse online, 305-327, Amsterdam, Benjamins.

Thorne, S.L. (2010), The 'Intercultural Turn' and Language Learning in the Crucible of New Media. In Guth S. and Helm F. (eds.), Telecollaboration 2.0: Language Literacies and Intercultural Learning in the 21st Century, 139-164, Bern, Peter Lang.

Thorne, S.L. \& Smith, B. (eds.) (2011). Second Language Acquisition Theories, Technologies, and Language Learning. CALICO Journal, 28(2).

Urry, J. (2002). Mobility and Proximity. Sociology, 36(2), 255-274.

Van Lier, L. (2004). The ecology and semiotics of language learning: A sociocultural perspective. Boston: Springer.

Ware, P. (2005) 'Missed communication in online communication: tensions in a German-American telecollaboration', Language Learning \& Technology 9(2): 64-89. 
Ware, P. D., \& O'Dowd, R. (2008). Peer Feedback On Language Form In Telecollaboration. Language Learning \& Technology, 12(1), 43-63.

Warschauer, M. (1996), Computer Assisted Language Learning: an Introduction, in: Fotos S. (ed.), Multimedia language teaching, 3-20, Tokyo, Logos International. Retrieved from http://www.ict4lt.org/en/warschauer.htm

Warschauer, M. (2006). Laptops and literacy: learning in the wireless classroom. Teachers College Press, Columbia University.

Warschauer, M. (2011). Learning in the cloud: How (and why) to transform schools with digital media. New York: Teachers College Press.

Received: 04/03/2016

Accepted: 20/05/2016 